\title{
Pengaruh Olahraga Jalan Cepat dan Diet terhadap Tekanan Darah Penderita Prahipertensi Pria
}

\author{
The Effect of Brisk Walking Exercise and Diet on Control Blood Pressure \\ Prehypertention Male
}

\author{
Mustafa Kamal* Dede Kusmana* Hardinsyah** Budi Setawan*** Rizal M. Damanik***
}

\begin{abstract}
*Fakultas Kedokteran Universitas Indonesia Rumah Sakit Umum Pusat Nasional Dr. Cipto Mangunkusumo, **Ilmu Gizi Institut Pertanian Bogor, ***Fakultas Ekologi Manusia Institut Pertanian Bogor
\end{abstract}

\begin{abstract}
Abstrak
Diet mengendalikan hipertensi orang Indonesia di Jakarta (dietary approach to stop hypertension for Indonesian at Jakarta, disingkat DASHI-J) dan olahraga jalan cepat dapat mengurangi berat badan dan menurunkan tekanan darah pada pasien prahipertensi. Tujuan penelitian ini adalah mengevaluasi diet dan olahraga tersebut dengan desain penelitian clinical trial terhadap 100 laki-laki berusia 25 - 55 tahun di PT Krama Yudha Ratu Motor. Responden dialokasikan secara acak dalam 4 kelompok perlakuan meliputi kelompok diet (A), kelompok olahraga jalan cepat (B), kelompok diet dan olahraga jalan cepat (C), dan kelompok kontrol (D). Kelompok $A$ dan $\mathrm{C}$ menerima diet 5 hari dalam seminggu selama 8 minggu. Kelompok diet DASHI-J diberikan makan siang dan makan malam. Setelah 2 bulan intervensi, berat badan, indeks massa tubuh, visceral fat, body fat, lingkar perut, tekanan darah sistolik dan diastolik, kolesterol serum dari semua kelompok menurun secara signifikan. Penurunan tertinggi terjadi pada kelompok diet DASHI-J dan olahraga jalan cepat dengan penurunan berat badan 4,18 $\mathrm{kg}$, indeks massa tubuh $1,50 \mathrm{~kg} / \mathrm{m}^{2}$, tekanan darah $12,00 \mathrm{mmHg} / 8,60$ $\mathrm{mmHg}$. Diet DASHI-J dan olahraga jalan cepat berperan menurunkan berat badan, indeks massa tubuh, serta tekanan darah sistolik dan diastolik. Kata kunci: DASHI-J, olahraga jalan cepat, prahipertensi, tekanan darah
\end{abstract}

\section{Abstract}

Dietary approach to stop hypertension for Indonesian at Jakarta (DASHI-J) and brisk walking exercise could reduce body weight and blood pressure of males prehypertension. The objective of the study was to evaluate DASHI-J by an experimental clinical trial conducted with 100 male subjects, aged 25 - 55 years divided randomly into 4 groups: DASHI-J diet group (A), brisk walking exercise group (B), DASHI-J and brisk walking exercise group (C), and control group (D). Group $A$ and $C$ got 5 days a week for 8 weeks diet. DASHI-J group was given lunch and dinner. After 2 months of intervension, the body weight, body mass index, body fat, visceral fat, waist circumference, systole, diastole, cholesterol serum of the groups all reduce significantly. The highest reduction of those intervention achieved by DASHI-J and brisk walking exercise group with body weight decreased 4.18 $\mathrm{kg}$, Body Mass Index (BMI) $1.50 \mathrm{~kg} / \mathrm{m}^{2}$, blood pressure $12.00 / 8.60 \mathrm{mmHg}$. This implies that DASHI-J and brisk walking exercise play a significant role in reducing body weight, BMI, and both sistolic and diastolic blood pressure. Keywords: DASHI-J, brisk walking exercise, prehypertension, blood pressure

\section{Pendahuluan}

Di negara maju dan negara berkembang, pengidap penyakit hipertensi memperlihatkan tren yang semakin meningkat. ${ }^{1}$ Di Indonesia, pada tahun 2002, prevalensi hipertensi di kalangan usia dewasa adalah $28 \% .^{2}$ Hasil Riset Kesehatan Dasar (Riskesdas) tahun 2007, prevalensi hipertensi memperlihatkan tren yang meningkat $(31,5 \%)$, sementara prevalensi prahipertensi adalah sekitar 32,0\%. ${ }^{3}$ Hasil Riskesdas tahun 2007, prevalensi hipertensi pada penduduk berumur 18 tahun ke atas di Indonesia adalah sekitar 31,7\%.

Peningkatan taraf hidup masyarakat dan tuntutan hidup serba cepat berpengaruh terhadap pola makan. Saat ini, masyarakat lebih memilih makanan siap saji yang umumnya rendah serat, tinggi lemak, tinggi gula, dan mengandung banyak garam. Pola makan kurang sehat memicu penyakit seperti hipertensi, jantung, diabetes melitus, dan obesitas. Kejadian penyakit tersebut juga cenderung mengalami peningkatan di Indonesia. Berbagai penyakit tersebut berdampak besar terhadap

Alamat Korespondensi: Mustafa Kamal, Departemen Ilmu Kedokteran Olahraga FK UI RSUP Dr. Cipto Mangunkusumo Jakarta Pusat, Jl. Salemba Raya 6, Jakarta, Hp.0811827840,e-mail:dr_mustafa_kamal@yahoo.com 
beban sosial ekonomi dan kesehatan masyarakat bagi keluarga, masyarakat, dan pemerintah.

Hipertensi berhubungan dengan berbagai faktor risiko meliputi faktor yang tidak dapat diubah seperti genetik, keadaan gizi, dan umur serta faktor yang dapat diubah seperti kegemukan, diet, dan aktivitas fisik. Di lain pihak, kegemukan disebabkan oleh konsumsi makanan berlebihan dan aktivitas fisik yang rendah. Dietary approach to stop hypertension (DASH) adalah diet rendah lemak jenuh, kolesterol, lemak total, dan menekankan pada konsumsi sayur, buah, dan susu rendah lemak. ${ }^{4}$ Di Amerika, hal tersebut terbukti dapat menurunkan tekanan darah sistolik (SBP). Menurut US Departement of Health Service, memelihara berat badan pada IMT $18,5-24,9 \mathrm{~kg} / \mathrm{m}^{2}$ dapat menurunkan tekanan darah sistolik (TDS) sekitar $5-20 \mathrm{mmHg} .{ }^{5}$ Penggunaan diet DASH dapat menurunkan SBP sebesar 8-14 $\mathrm{mmHg}$, mengurangi konsumsi garam (tidak lebih dari 6 gram per hari) dapat menurunkan SBP sebanyak $2-8$ $\mathrm{mmHg}$, dan melakukan aktivitas fisik (30 menit per hari) dapat menurunkan SBP sekitar $4-9 \mathrm{mmHg}$. Sehubungan dengan upaya preventif prahipertensi, faktor risiko yang dapat diubah tersebut perlu dikelola dengan baik, antara lain melalui perubahan perilaku makan, kesehatan, serta aktivitas sehat yang lain.

Dalam program diet, olahraga merupakan salah satu faktor yang sangat menentukan. Olahraga intensitas rendah serta durasi lama dan rutin, secara efektif dapat mengikis lemak tubuh. ${ }^{6}$ Pada laki-laki berusia 40 tahun dengan aktivitas fisik sedang, jalan kaki mampu membakar kalori dalam jumlah yang besar. Dengan kecepatan 2 mil per jam selama 30 menit, jalan kaki dapat membakar kalori 64,9 kkal, dan jika ditingkatkan menjadi 4 mil per jam selama 30 menit dapat membakar kalori 186,7 kkal. ${ }^{6}$ Penelitian ini bertujuan menganalisis efikasi olahraga jalan cepat dan diet DASHI-J terhadap penurunan tekanan darah dan nadi pada minggu kedua,keempat, keenam, dan kedelapan, lemak darah, dan elektrolit darah.

\section{Metode}

Penelitian dengan desain studi eksperimental randomized clinical trial (RCT) ini meneliti populasi penderita prahipertensi di PT Krama Yudha Ratu Motor Pulogadung Jakarta Timur selama dua bulan. Penelitian pendahuluan dengan desain cross sectional dilakukan pada awal tahun 2010 dan dilanjutkan dengan penelitian eksperimental pada awal Juni hingga akhir Juli 2011. Subjek penelitian dibagi atas empat kelompok secara acak meliputi kelompok A yang mendapat perlakuan diet DASHI-J, kelompok B mendapat perlakuan olahraga berjalan cepat, kelompok $\mathrm{C}$ mendapat perlakuan olahraga berjalan cepat dan diet DASHI-J, dan kelompok D sebagai kelompok kontrol. Pelaksanaan intervensi diet DASHI-J adalah penerapan diet DASHI-R (3), dengan sedikit modifikasi sesuai dengan pola makan masyarakat Jakarta, khususnya karyawan PT Krama Yudha Ratu Motor.

Menu dengan siklus lima hari diuji coba menggunakan bumbu yang sesuai, semua bahan yang digunakan ditimbang, garam diberikan dalam makanan sebanyak 0,5 gram/porsi/orang. Hasil uji coba menu menghasilkan menu standar untuk digunakan dalam penelitian ini. Makanan yang disediakan untuk kelompok A dan C meliputi makan siang, selingan sore, dan makan malam. Makan pagi disediakan sendiri oleh subjek. Peneliti memberikan petunjuk tentang jumlah dan jenis makan pagi, selingan pagi, dan selingan malam. Diet mulai diberikan satu sampai dua hari setelah pengumpulan data dasar. Untuk kelompok A dan C makanan diantar dua kali ke PT sekitar pukul 11.00 untuk makan siang dan sekitar pukul 15.00 untuk selingan sore dan makan malam. Selingan sore yang berupa jus buah diminta untuk dikonsumsi sebelum pulang ke rumah, sedangkan untuk makan malam dibawa pulang ke rumah.

Diet diberikan lima hari dalam seminggu selama delapan minggu dan jumlah energi yang dikurangi secara bertahap 500 kalori per hari dalam dua minggu pertama, selanjutnya dikurangi 800 kalori per hari, dengan kalori terendah 1.700 kalori per hari. Data konsumsi dikumpulkan dengan kombinasi pencatatan makanan dan penimbangan. Sebelum diet diberikan, makanan ditimbang, makanan sisa diminta diletakkan pada tempat makan yang disediakan dan dibawa pulang dan ditimbang, ketika enumerator mengantar makanan selanjutnya. Subjek diminta mencatat makanan yang dikonsumsi di rumah.

Program olahraga jalan cepat 6 - $7 \mathrm{~km} / \mathrm{jam}$ dilakukan dengan intensitas $65-75 \%$, denyut jantung maksimal, lama 45 menit, dengan frekuensi $5 \mathrm{kali} / \mathrm{minggu}$, selama 8 minggu. Olahraga jalan cepat dipimpin seorang instruktur olahraga dari Universitas Negeri Jakarta pada pukul 05.00 - 06.30 WIB di lapangan terbuka PT Krama Yudha Ratu Motor, didahului dengan pemanasan selama 5 - 10 menit, dan dilanjutkan dengan berjalan cepat selama 45 menit. Setelah olahraga, denyut jantung dihitung untuk menentukan status masuk zona pelatihan, dilanjutkan dengan pendinginan dengan berjalan perlahan dan peregangan selama 5 - 10 menit.

Penjaminan kualitas data dilakukan dengan langkah pengendalian mutu yang meliputi rekrutmen enumerator, pretest kuesioner, dan daftar isian atau code book, panduan pengumpulan data dan kuesioner, verifikasi data, dan supervisi. Data yang terkumpul dari kuesioner, wawancara, pemeriksaan klinis, laboratorium, pengukuran antropometri yang meliputi tinggi badan, berat badan, indeks massa tubuh, body fat, visceral fat, lingkar perut, serta hasil analisis diolah hingga siap dianalisis 
Tabel 1. Diet DASHI-J, DASHI-R, dan DASH

\begin{tabular}{llll}
\hline Makanan & \multicolumn{1}{c}{ DASHI-J } & DASHI-R & DASH \\
\hline Sumber karbohidrat & $3-8$ porsi / hari & $2-5.5$ porsi / hari & $7-8$ porsi / hari \\
Sayur & $4-6$ porsi / hari & $3-4$ porsi / hari & $4-5$ porsi / hari \\
Buah & $5-6$ porsi / hari & $5-6$ porsi / hari & $4-5$ porsi / hari \\
Lauk & $3-7$ porsi / hari & $2-3$ porsi / hari & 2 porsi / hari \\
minyak & $2-3$ porsi / hari & $2-3$ porsi / hari & $2-3$ porsi / hari \\
Kacang - kacangan & $4-5$ porsi / minggu & $4-5$ porsi / minggu & $4-5$ porsi / minggu \\
Susu rendah lemak & 1 porsi & 1 porsi & $2-3$ porsi / hari \\
Makanan manis & & & 5 porsi / minggu \\
Konsumsi garam & 5 gram / hari & 3.5 gram / hari & 5 gram / hari \\
& (2000 mg Na) & & \\
\hline
\end{tabular}

Tabel 2. Jumlah Porsi Diet DASHI-J Berdasarkan Energi

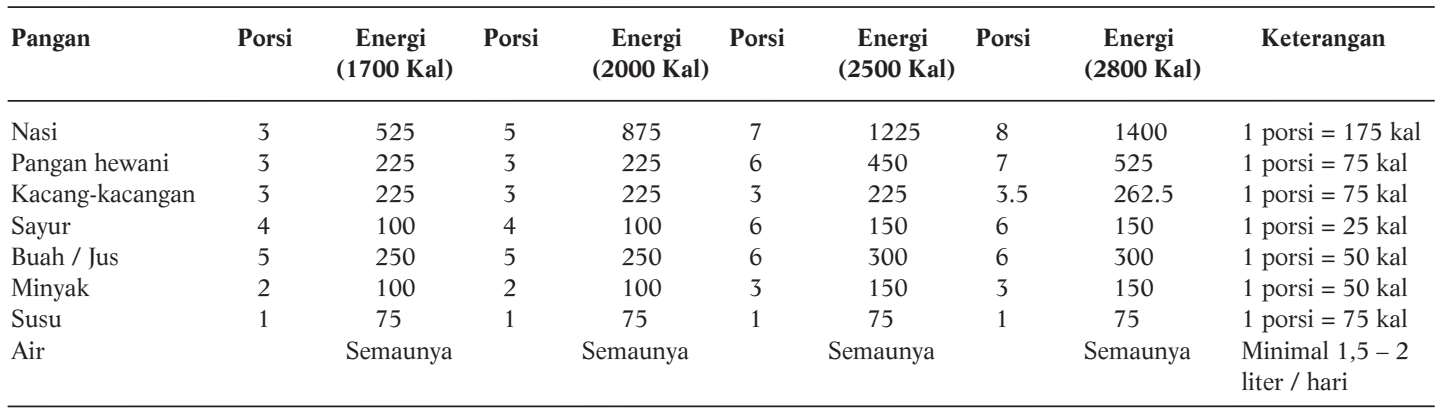

menggunakan software analisis data. Sebelum dilakukan uji statistik lanjut, seluruh perubah disajikan dalam bentuk statistik elementer meliputi nilai rata-rata, standar deviasi, rentang, dan frekuensi.

\section{Hasil}

Pelaksanaan intervensi diet DASHI-J adalah penerapan diet DASHI-R dengan sedikit modifikasi sesuai dengan pola makan masyarakat Jakarta. Penerapan diet tersebut dikhususkan pada karyawan PT Krama Yudha Ratu Motor, seperti dijelaskan pada Tabel 1 dan Tabel 2.

\section{Efikasi Olahraga Jalan Cepat dan Diet DASHI-J terhadap Tekanan Darah dan Nadi}

Gambar 1. menunjukkan penurunan secara bermakna (nilai $\mathrm{p}<0,05$ ) variabel tekanan darah sistolik dan diastolik serta denyut nadi. Variabel tekanan nadi juga terlihat menurun, tetapi secara statistik tidak bermakna (nilai $\mathrm{p}>0,05$ ).

Tekanan darah pada minggu kedua, keempat, keenam, dan kedelapan terlihat pada penurunan secara nyata pada variabel sistolik dan diastolik pada minggu kedua, keempat, keenam, dan kedelapan (Gambar 2).

\section{Efikasi Olahraga Jalan Cepat dan Diet DASHI-J terhadap Lemak Darah}

Variabel kolesterol, LDL, dan trigliserida memperlihatkan kecenderungan yang menurun sehingga tidak ter- dapat perbedaan yang bermakna (nilai $\mathrm{p}>0,05$ ). Namun, untuk variabel HDL justru mengalami peningkatan, tetapi secara statistik tidak berbeda bermakna (nilai $p$ > 0,05) (Gambar 3).

Efikasi olahraga jalan cepat dan diet DASHI-J terhadap elektrolit darah terlihat bahwa variabel natrium dan kalium berbeda secara bermakna (nilai $\mathrm{p}<0,05$ ). Khusus pada kelompok D, variabel kalium memperlihatakan sedikit kenaikan, tetapi tidak berbeda secara bermakna (nilai $\mathrm{p}>0,05)($ Gambar 4).

\section{Pembahasan}

Karakteristik sosial ekonomi antarkelompok perlakuan mengidentifikasikan terjadi pengacakan yang cukup baik pada keempat kelompok awal penelitian. Hasil penelitian ini tidak jauh berbeda dengan penelitian Harahap et al. ${ }^{4}$

Asupan garam natrium diet DASHI-J 2.000 mg/hari dibandingkan dengan standar pemberian garam yang ditetapkan pada penuntun diet dan angka kecukupan gizi Indonesia. 7,8 Rata-rata konsumsi kalium/hari pada penelitian ini 2.936,40 dan 3.114,52 mg tak jauh berbeda dengan penelitian DASHI-R 3.393 dan $3.389 \mathrm{mg}$ dan lebih rendah dari diet DASH $4415 \mathrm{mg} /$ hari sejalan dengan Dickinson et al dan ADA dosis potassium antara 1.900 sampai $4.700 \mathrm{mg} / \mathrm{hari}$ dapat menurunkan diastolik 2-6 $\mathrm{mmHg}$ dan $2-4 \mathrm{mmHg}$ sistolik. ${ }^{9-11}$

Pada penelitian ini penurunan tekanan sistolik 


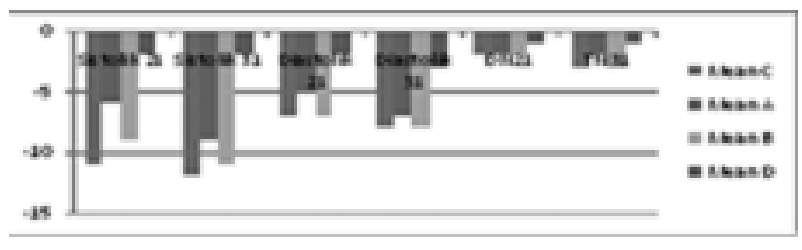

Gambar 1. Penurunan Tekanan Darah dan Nadi bulan 0-2

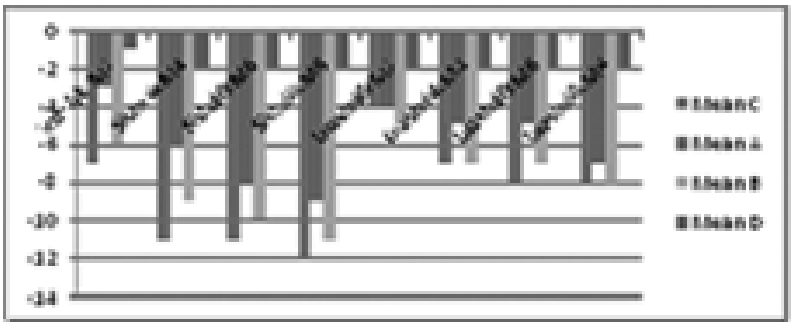

Gambar 2. Penurunan Tekanan Darah Minggu ke 2, 4, 6 dan 8

DASHI-J sebanyak -9,5, sementara DASHI-J dan olahraga jalan cepat sebanyak -12,00. Penurunan sistolik olahraga jalan cepat menyebabkan volume ventrikel dan isi sekuncup meningkat lebih besar, laju jantung dan curah jantung menurun lebih besar serta shear stress meningkat, produksi NO meningkat, dilatasi arteriol. Olahraga jalan cepat meningkatkan beban volume sehingga meningkatkan volume ventrikel. Pada penelitian ini olahraga jalan cepat menurunkan denyut jantung istirahat lebih besar yang selanjutnya akan menurunkan curah jantung, sehingga menurunkan tekanan sistolik. ${ }^{12}$ Penurunan tekanan darah yang kecil ternyata sudah dapat mengurangi risiko terhadap kejadian penyakit kardiovaskular dan stroke. Penurunan tekanan darah sebesar $2 \mathrm{mmHg}$ akan mengurangi risiko penyakit kardiovaskular dan stroke sebesar $4 \%$ dan $6 \% .{ }^{13}$ Bila penurunan tekanan darah akibat perlatihan aerobik sebesar 8,6 - $16 \mathrm{mmHg}$, risiko penyakit kardiovaskular akan berkurang sebesar $16-32 \%$ dan stroke sebesar $24-48 \%$.

Penurunan tekanan diastolik DASHI-J $(-7,5)$, DASHI-J dan olahraga jalan cepat $(-8,60)$ tidak jauh berbeda dengan penelitian Harahap $\mathrm{H}$, et al: sistolik D $(-11,7)$, DK $(-11,7)$, diastolik D $(-6,2)$ DK $(-9,5)$. Olahraga jalan cepat saja dapat menurunkan tekanan sistolik maupun diastolik. ${ }^{4}$ Pada penelitian ini, penurunan berat badan diet DASHI-J sebesar -2,19, diet DASHI-J dan olahraga jalan cepat sebesar $-4,18$. Hasil penelitian sejalan dengan pendapat dari beberapa pakar seperti Wong-Ho Chow, et al dan Liebert, et al yang menyatakan bahwa obesitas berisiko menyebabkan hipertensi sebesar $2-6$ kali dibanding yang bukan obesitas. Indeks massa tubuh DASHI-J sebesar $-1,10), 14,15$ sedangkan diet DASHI-J dan olahraga jalan cepat -1,5 lebih tinggi dari penelitian Harahap

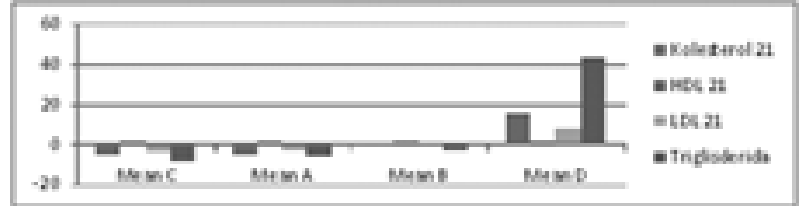

Gambar 3. Penurunan Lemak Darah bulan 0-2

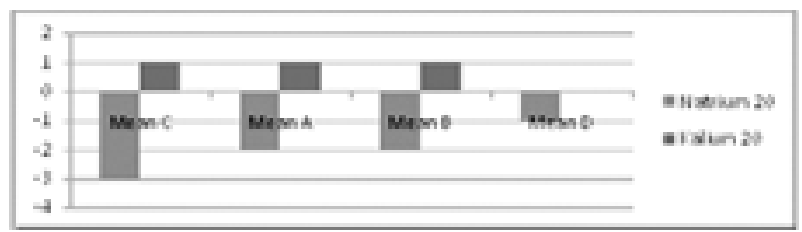

Gambar 4. Penurunan Elektrolit Darah bulan 0-2

$\mathrm{H}$, et al dan diet DASHI-R: $-1,0$ dan diet + konseling -3,7. Indeks massa tubuh $-0,4$ dan $-1,5$ lebih rendah dari penelitian Appel et al. ${ }^{4}$

Penurunan kolesterol darah DASHI-J sebesar -5,64 dan DASHI-J dan olahraga jalan cepat -6,44 lebih tinggi dibandingkan Harahap et al D -0,9 dan DK -5,2. Peningkatan elektrolit kalium DASHI-J sebesar 0,65 serta DASHI-J dan olahraga jalan cepat 0,78 lebih tinggi dari penelitian Harahap H, et al D 0,5 dan DK 1,00. ${ }^{4}$ Bila kadar kalium dalam serum turun dibawah $3 \mathrm{mg} / \mathrm{L}$ akan terjadi gangguan jantung. Bila kadar kalium meningkat menjadi $7-8 \mathrm{mg} / \mathrm{L}$ seperti pada penderita gagal ginjal kronis akan mengakibatkan otot jantung tidak bekerja dengan baik bahkan dapat mengakibatkan gagal jantung. ${ }^{16}$

\section{Kesimpulan}

Diet DASHI-J dan olahraga jalan cepat (C) lebih efektif menurunkan tekanan darah sistolik dan diastolik pada minggu kedua, keempat, keenam, dan kedelapan daripada diet DASHI-J (A), olahraga jalan cepat (B), dan kontrol (D). Diet DASHI-J dan olahraga jalan cepat menurunkan tekanan darah sistolik dan diastolik, tekanan, dan natrium darah serta meningkatkan kalium darah lebih baik daripada diet DASHI- J, olahraga jalan cepat, dan kontrol.

\section{Saran}

Upaya pencegahan hipertensi dan kegemukan pada penderita prahipertensi dan atau berat badan lebih dapat dilakukan dengan menerapkan olahraga jalan cepat dan diet DASHI-J. Dalam upaya peningkatan kesehatan dan kebugaran para karyawan, diperlukan klinik konsultasi gizi dan olahraga. Diperlukan dukungan kebijakan dalam manajemen PT Krama Yudha Ratu Motor untuk memastikan program olahraga jalan cepat dan diet DASHI terlaksana. 


\section{Daftar Pustaka}

1. Appel LJ, Champagne CM, Harsha D, Cooper LS. Effects of comprehensive lifestyle modification on blood pressure control. Journal of the American Diatetic Association. 2003; 289: 2083-93.

2. Badan Penelitian dan Pengembangan Kesehatan. Survei Kesehatan Rumah Tangga. Jakarta: Badan Penelitian dan Pengembangan Kesehatan; 2002.

3. Badan Penelitian dan Pengembangan Kesehatan Departemen Kesehatan Republik Indonesia. Riset kesehatan dasar (Riskesdas) 2007. Laporan Riset Nasional. Jakarta: Departemen Kesehatan Republik Indonesia; 2008 [diakses tanggal 28 Maret 2008]. Diunduh dari: http: //www.litbang.depkes.go.id/laporan.

4. Harahap H. Pengaruh diet penurunan berat badan dan tekanan darah pada penderita prahipertensi yang kegemukan [disertasi]. Bogor: Institut Pertanian Bogor; 2009.

5. United States Departemen of Health and Human Services (USDHHS). The DASH eating plan. Washington: United States Departemen of Health and Human Services; 2004.

6. Oentoro S. Diet DASH natrium untuk penderita hipertensi tahun 2006: olahraga apa efektif bakar lemak [diakses tanggal 2010 Apr 11]. Diunduh dari: http://www.ayo vege.com.

7. Almatsier S. Buku penuntun diet. Jakarta: PT Gramedia; 2005.

8. Hardinsyah TV. Angka kecukupan energi, protein, lemak, dan serat makanan. Widyakarya Nasional Pangan dan Gizi XIII. 2004 May 17-19; Jakarta. Jakarta: Lembaga Ilmu Pengetahuan Indonesia; 2004.

9. Appel LJ, Moore TJ, Obarzanek E. A clinical trial of the effect of dietary patterns on blood pressure. The New England Journal of Medicine. 1997; 336: 1117-23.

10. Dickinson HO, Nicolson DJ, Campbell F, Boyer FR, Cook JV. Lifestyle interventions to reduce raised blood pressure: a systematic review of randomized, controlled trials. Journal of Hypertension 2006; 24: 215.

11. American Dietetic Association. Hypertension, ADA evidence analysis library. Chicago: American Dietetic Association; 2009.

12. Sherwood L. Human physiology: from cells to system. $5^{\text {th }}$ ed. Belmont CA: Thomson Brooks/Cole; 2004.p.375-9.

13. Mc Ardle WD, Katch FI, Katch VL, ed. Muscular strength: training muscles to become stronger. In: Essentials of exercise physiology. $3^{\text {rd }}$ ed. USA: Lipincott Williams \& Wilkins; 2006.p.469-509.

14. Wong-Ho C, Gerdley Gl, Fraumeni JF. Obesity, hypertension and the risk of kidney cancer in men. The New England Journal of Medicine. 2000; 17: 1305-6.

15. Liebert MA. Transgenerational persistence of education as a health risk. The Journal of Womens Health. 2003: 12 (5); 505-12.

16. Riyadi H. Penilaian Gizi secara Antropometri [unpublished manuscript]. Bogor: Jurusan Gizi Masyarakat dan Sumberdaya Keluarga, Fakultas pertanian, Institut Pertanian Bogor; 2007. 